\title{
The Ethnic Profile of Triple-Negative Breast Cancer
}

\author{
Susan J. Cleator ${ }^{a} \quad$ Carlo Palmieri $^{\mathrm{b}} \quad$ Charles R. Coombes ${ }^{\mathrm{b}}$ \\ a Department of Oncology, St Mary's Hospital (Imperial Healthcare NHS Trust), London, \\ ${ }^{b}$ Cancer Research UK Laboratories, Department of Cancer Medicine, Imperial College London, UK
}

The article in this issue of OnKOLOGIE by Tian et al. [1] describing a series of triple negative breast cancers in a population of Chinese women joins the growing literature describing this sub-class of breast cancer within specific ethnic groupings. The immunohistochemical phenotype of oestrogen receptor (ER), progesterone receptor $(\mathrm{PgR})$ and the HER-2 receptor negative breast cancer has been apparent for many years but its existence was highlighted by the expression RNA microarray work of Perou et al. and others that demonstrated a molecularly distinct group of breast cancers characterized by under expression of these three receptors, up-regulation of components of proliferation pathways and an expression profile that clustered with that of breast cancers arising in BRCA 1 mutation carriers $[2,3]$.

The triple negative subgroup overlaps with the morphologically distinct group of 'basal-like breast cancers', characterized by high mitotic count, central necrosis, frequent apoptotic cells, a stromal lymphocytic response and expression of myoepithelial markers (cytokeratins 5, 6, 14 and 17) $[4,5]$. The triple negative subgroup of breast cancers is not homogeneous in terms of morphology, as it includes cancers with metaplastic, atypical or typical medullary and adenoid cystic appearance [4-7].

Clinically, triple negative cancers are characterized by high probability of systemic disease, and in particular development of lung and brain metastases [8,9]. However, there is again hetererogeneity as some subgroups, for example adenoid cystic carcinoma of the breast, are associated with an excellent prognosis [10]. Despite their aggressive natural history, triple negative breast cancers are more likely to achieve a complete pathological response to pre-operative chemotherapy (pCR) than other breast cancer types [11], and it appears that these patients with marked chemosensitivity have a relatively good chance of long-term survival [12]. Furthermore, although most studies demonstrate an association between the triple negative phenotype and poor outcome, some studies suggest that this negative association loses significance after 10 years, suggesting that patients that survive the first few years are no more likely to relapse than other breast cancer sub-types $[13,14]$. Thus, universal negativism about triple negative breast cancer may not be justified.

The profile of breast cancer in terms of age of onset and age distribution of molecular subgroups of the disease varies across the major ethnic subgroups, with Asian populations appearing demographically distinct. It is clear that incidence of breast cancer is much lower in Asian as compared to other ethnic groups. An analysis of data from the Surveillence, Epidemiology, and End Results (SEER) database and Osaka Cancer Registry (1978-97) showed overall age-adjusted incidence rates per 100,000 woman-years were highest in Whites (in SEER) (87.6), followed by Blacks (in SEER) (80.0) and lowest in Osaka (21.8). The Japanese population in this study was distinct in lacking the preponderance of postmenopausal breast cancer seen in both White and Black populations [15]. This preponderance of postmenopausal breast cancer in White and Black populations has been attributed to a complex interplay of life style factors [16] and access to healthcare, in particular breast screening [17]. It is not clear to what extent the demographics of Black Americans reflect those in other Black populations and indeed how representative the Japanese population is of other Asian ethnic subgroups.

Much has been written about the triple negative breast cancer in Western populations where it accounts for approximately $10-15 \%$ of all breast cancer cases $[4,18]$. It has been consistently reported that the triple negative phenotype is proportionally more common in Black populations including women with Nigerian ancestry (58\% in one study) [19] and within African populations in the US (20-21\%) [18, 20], with a striking preponderance for pre-menopausal women. This demographic may be in part due to underlying host (germ-line) genetic factors, including inherited polymorphisms. However, a case-control study of African American and White women (the Carolina Breast Cancer Study) showed that basal cancer cases were associated with exposure of a set of 'basal breast cancer risk factors', namely multiple live births which did not

\section{KARGER}

Fax +497614520714

Information@Karger.de

www.karger.com
(C) 2008 S. Karger GmbH, Freiburg

Accessible online at:

www.karger.com/onk
Dr. Susan J. Cleator MRCP FRCR PhD

Department of Oncology

St Mary's Hospital (Imperial Healthcare NHS Trust)

Praed St, London, W2 1NY, UK

Tel. +44 207 8861-132, Fax -840

s.cleator@imperial.ac.uk 
breast feed, younger age at first full-term pregnancy, use of medications to suppress lactation and elevated waist-hip ratio [21]. The authors suggest that $68 \%$ of basal-like breast cancer could be prevented by promotion of breast feeding and reduction of abdominal adiposity.

Relatively little has been written about this disease entity within Asian populations, and in particular Chinese populations. Within the small cohort of 116, presumably unselected, breast cancer patients described in this paper, the median age at diagnosis was 47 years and the triple negative immunophenotype accounted for $19 \%$ of cases with a median age of onset of 50 years. A Korean study of 776 female breast cancer cases reported a similar proportion $(14.7 \%)$ of cancers to be basal-like, defined by immunopositivity for one or more basal markers and triple negativity, and a similar mean age of diagnosis (47.7 years) [22]. However, a Japanese study of 793 breast cancer cases reported only $7 \%$ of cancers to be triple negative, and the median age was slightly higher at 54 years [23]. It is also noteworthy that the triple negative phenotype in this population of Japanese women was associated with a 5 -year overall survival of $86.2 \%$, much higher than in many other series. Comparisons between studies must be undertaken with caution and while these discrepancies may be due to the small numbers concerned, differences in the intrinsic biology of breast cancer in different Asian populations or issues around access to healthcare cannot be excluded.
Very few conclusions can be drawn from this cohort of 22 cases of triple negative breast cancer, but, in keeping with other series, it suggests inferior outcome relative to other breast cancer types. As compared to 94 cases of 'non-triple negative cancer', and with a long median follow-up (96 months), $54.3 \%$ of the triple negative cases developed distant relapse compared to $21.2 \%(\mathrm{p}<0.05)$. This difference is striking but information relating to the clinicopathological features of the 'non triple negative group' is lacking.

To date, all the published data with regard to Asian women has been based on immunohistochemical phenotype and no molecular based studies exist. Such studies would be of interest in terms of examining whether there are any differences between the molecular signature of 'Western triple negative' as compared to an 'Asian triple negative' breast cancer, or indeed any differences between different Asian sub-populations.

One fifth of the world's women live in China. Whilst the incidence of breast cancer in most of China is currently low compared with the Western world, the incidence is rising rapidly in Shanghai [24] and Hong Kong [25] and set to rise elsewhere in the country as lifestyles change. Careful documentation of the changes in the incidence and composition of breast cancer in relation to lifestyle over the next few years may help our understanding of the biology of breast cancer and help China respond with an evolving epidemic.

\section{References}

1 Tian XS, Cong MH, Zhou WH, Zhu J, Chen YZ, Liu Q: Clinicopathologic and prognostic characteristics of triple negative breast cancer. Onkologie 2008;31:610-614.

2 Perou CM, Sorlie T, Eisen MB, van de Rijn M, Jeffrey SS, Rees CA, Pollack JR, Ross DT, Johnsen $\mathrm{H}$, Akslen LA, Fluge O, Pergamenschikov A, Williams C, Zhu SX, Lonning PE, Borresen-Dale AL, Brown PO, Botstein D: Molecular portraits of human breast tumours. Nature 2000;406:747-752.

>3 Sorlie T, Tibshirani R, Parker J, Hastie T, Marron JS, Nobel A, Deng S, Johnsen H, Pesich R, Geisler $\mathrm{S}$, Demeter J, Perou CM, Lonning PE, Brown PO, Borresen-Dale AL, Botstein D: Repeated observation of breast tumor subtypes in independent gene expression data sets. Proc Natl Acad Sci U S A 2003;100:8418-8423.

4 Abd El-Rehim DM, Ball G, Pinder SE, Rakha E, Paish C, Robertson JF, Macmillan D, Blamey RW, Ellis IO: High-throughput protein expression analysis using tissue microarray technology of a large well-characterised series identifies biologically distinct classes of breast cancer confirming recent cDNA expression analyses. Int J Cancer 2005;116: 340-350.

$\checkmark 5$ Abd El-Rehim DM, Pinder SE, Paish CE, Bell J, Blamey RW, Robertson JF, Nicholson RI, Ellis IO: Expression of luminal and basal cytokeratins in human breast carcinoma. J Pathol 2004;203:661-671.
6 Lamovec J, Us-Krasovec M, Zidar A, Kljun A: Adenoid cystic carcinoma of the breast: a histologic, cytologic, and immunohistochemical study. Semin Diagn Pathol 1989;6:153-164.

7 Tot T: The cytokeratin profile of medullary carcinoma of the breast. Histopathology 2000;37:175-181. 8 Rodriguez-Pinilla SM, Sarrio D, Honrado E, Hardisson D, Calero F, Benitez J, Palacios J: Prognostic significance of basal-like phenotype and fascin expression in node-negative invasive breast carcinomas. Clin Cancer Res 2006;12:1533-1539.

9 Tsuda H, Takarabe T, Hasegawa F, Fukutomi T, Hirohashi S: Large, central acellular zones indicating myoepithelial tumor differentiation in highgrade invasive ductal carcinomas as markers of predisposition to lung and brain metastases. Am J Surg Pathol 2000;24:197-202.

10 Azoulay S, Lae M, Freneaux P, Merle S, Al Ghuzlan A, Chnecker C, Rosty C, Klijanienko J, SigalZafrani B, Salmon R, Fourquet A, Sastre-Garau X, Vincent-Salomon A: KIT is highly expressed in adenoid cystic carcinoma of the breast, a basal-like carcinoma associated with a favorable outcome. Mod Pathol 2005;18:1623-1631.

11 Guarneri V, Broglio K, Kau SW, Cristofanilli M, Buzdar AU, Valero V, Buchholz T, Meric F, Middleton L, Hortobagyi GN, Gonzalez-Angulo AM: Prognostic value of pathologic complete response after primary chemotherapy in relation to hormone receptor status and other factors. J Clin Oncol 2006;24:1037-1044.
12 Carey A, Dees C, Sawyer L, Gatti L, Moore D, Collichio F, Ollila D, Sartor C, Graham M, Perou C: The triple negative paradox: primary tumour chemosensitivity of breast cancer subtypes. Clinical Cancer Research 2007;13:2329-2334.

13 Jumppanen M, Gruvberger-Saal S, Kauraniemi P, Tanner M, Bendahl PO, Lundin M, Krogh M, Kataja P, Borg A, Ferno M, Isola J: Basal-like phenotype is not associated with patient survival in estrogen-receptor-negative breast cancers. Breast Cancer Res 2007;9:R16.

14 Langerod A, Zhao H, Borgan O, Nesland JM, Bukholm IR, Ikdahl T, Karesen R, Borresen-Dale AL, Jeffrey SS: TP53 mutation status and gene expression profiles are powerful prognostic markers of breast cancer. Breast Cancer Res 2007;9:R30.

15 Glass AG, Lacey JV, Jr., Carreon JD, Hoover RN: Breast cancer incidence, 1980-2006: combined roles of menopausal hormone therapy, screening mammography, and estrogen receptor status. J Natl Cancer Inst 2007;99:1152-1161.

16 Nelson N: Migrant Studies Aid the Search for Factor Linked in Breast Cancer Risk. JNCI 2006:436338.

17 Carey LA, Dees EC, Sawyer L, Gatti L, Moore DT, Collichio F, Ollila DW, Sartor CI, Graham ML, Perou CM.: The triple negative paradox: primary tumor chemosensitivity of breast cancer subtypes. Clin Cancer Res 2007;13:2329-2334. 
18 Morris GJ, Naidu S, Topham AK, Guiles F, Xu Y, McCue P, Schwartz GF, Park PK, Rosenberg AL Brill K, Mitchell EP: Differences in breast carcinoma characteristics in newly diagnosed AfricanAmerican and Caucasian patients: a single-institution compilation compared with the National Cancer Institute's Surveillance, Epidemiology, and End Results database. Cancer 2007;110:876-884.

19 Olopade OI, Ikpatt F, Perou CM: Intrinsic Gene Expression subtypes correlated with grade andmorphometric parameters reveal a high proportion of aggressive basal-like tumors among black women of African ancestry. ASCO 2004:abstr 9509.
20 Carey LA, Perou CM, Livasy CA, Dressler LG, Cowan D, Conway K, Karaca G, Troester MA, Tse CK, Edmiston S, Deming SL, Geradts J, Cheang MC, Nielsen TO, Moorman PG, Earp HS, Millikan RC: Race, breast cancer subtypes, and survival in the Carolina Breast Cancer Study. JAMA 2006;295: 2492-2502.

21 Millikan RC, Newman B, Tse CK, Moorman PG, Conway K, Smith LV, Labbok MH, Geradts J, Bensen JT, Jackson S, Nyante S, Livasy C, Carey L, Earp HS, Perou CM: Epidemiology of basal-like breast cancer. Breast Cancer Res Treat 2008;109: 123-139.
2 Kim MJ, Ro JY, Ahn SH, Kim HH, Kim SB, Gong $\mathrm{G}$ : Clinicopathologic significance of the basal-like subtype of breast cancer: a comparison with hormone receptor and Her2/neu-overexpressing phenotypes. Hum Pathol 2006;37:1217-1226.

23 Kurebayashi J, Moriya T, Ishida T, Hirakawa H, Kurosumi M, Akiyama F, Kinoshita T, Takei H, Takahashi K, Ikeda M, Nakashima K: The prevalence of intrinsic subtypes and prognosis in breast cancer patients of different races. Breast 2007;16 (Suppl 2):S72-S77.

24 Parkin D, Whelan S, Ferley J, Storm H: Cancer Incidence in Five Continents. Lyon, IARC Cancer Base, 2005.

25 Leung G, Thach T, Lam T: Trends in breast cancer incidence in Hong Kong between 1973 and 1999: and age-period-cohort analysis. Br J Cancer 2002; 97:982-988. 